\title{
Investigation of optimum conditions for the growth of Fusarium solani EGY1 causing root rot of guar (Cyamopsis tetragonoloba $\mathbf{L}$.)
}

\author{
Simranjit Singh ${ }^{1}$ and Upasana Rani², U.S. Tiwana ${ }^{2}$, Devinder Pal Singh ${ }^{2}$ and Asmita \\ Sirari $^{2}$ \\ ${ }^{1}$ Department of Plant Pathology, Punjab Agricultural University, Ludhiana-141004 (Punjab), INDIA \\ ${ }^{2}$ Department of Plant Breeding and Genetics, Punjab Agricultural University, Ludhiana-141004 (Punjab), INDIA \\ *Corresponding author. E-mail: simran.badhan27@gmail.com \\ Received: January 13, 2017; Revised received: May 13, 2017; Accepted: October 15, 2017
}

\begin{abstract}
Guar gum (Galactomannan) is extracted from Guar (Cluster bean), which is extensively used in petroleum, food and pharmaceutical industry. Root rot of guaris caused by Fusarium solani EGY1 under Punjab, having sub-tropical climatic conditions. This study was undertaken to evaluate different culture media, grain substrates (sorghum, maize, cowpea, guar and pearl millet), temperatures $\left(20,25,30,35^{\circ} \mathrm{C}\right)$, pH levels $(5.0,6.0,7.0,8.0)$,light and darkness for the identification of optimum conditions for the growth and sporulation of the fungus. Czapek's dox mediawas found to be best for growth $(84.65 \mathrm{~mm})$ and sporulation $\left(1.8 \times 10^{4}\right.$ microconidia and $3.0 \times 10^{4}$ macro conidia) of fungus. For mass multiplication of the fungus, sorghum grains proved to be the best substrate. The fungus showed maximum radial growth at temperature of $25^{\circ} \mathrm{C}(84.36 \mathrm{~mm})$ and $\mathrm{pH}$ of $6.0(84.43 \mathrm{~mm})$ whereas sporulation was highest at $30^{\circ} \mathrm{C}\left(2.0 \times 10^{4}\right.$ microconidia and $3.2 \times 10^{4}$ macroconidia) and $\mathrm{pH}$ of $8.0\left(1.8 \times 10^{4}\right.$ microconidia and3.1 $\times 10^{4}$ macroconidia) respectively. Continuous light favoured radial growth $(84.62 \mathrm{~mm})$ whereas sporulation $\left(1.8 \times 10^{4}\right.$ microconidia and $3.1 \times 10^{4}$ macroconidia) was favoured by darkness.
\end{abstract}

Keywords: Fusarium solani EGY1, Light, Media, pH, Temperature

\section{INTRODUCTION}

Cluster bean [Cyamopsis tetragonoloba (L.)Taub.], a legume commonly known as guar, is rich in nutrients with crude protein content and total digestible nutrients on dry matter basis of 18.1 and 60.0 per cent respectively. It is widely used for fodder and vegetable purposes (Ayub et al., 2011). It has an economic importance in international market as its important component glactomannan known as guar gum is extensivelyused in petroleum, food and pharmaceutical industry (Sortino and Gresta, 2007). Area under cluster bean in India was 5.6 million ha with production and productivity of 2.7 million tonnes and $485 \mathrm{~kg}$ per ha, respectively during 2013-14. Rajasthan is the major cluster bean growing states of India. Punjab and Haryana also contributes significantly towards the production of cluster bean (Anonymous, 2014). Although, cluster bean being a hardy crop is very sensitive to biotic and abiotic stresses. The crop succumbs to number of diseases caused by fungi, bacteria and viruses. Of all the diseases, pathogen associated with root rot of guar is identified and confirmed as Fusarium solani strain EGY 1 by Singh et al., (2016). It causes heavy losses in summer sown crop and damage is visible even on young plants. Attacks of the Fusarium wilt pathogen can destroy the crop completely and can cause significant annual yield losses (Pareek and Varma, 2015).
Under Punjab conditions, this disease is associated with Fusarium solani EGY1. Present work depicts the role of different $\mathrm{pH}$, temperature, substrate and alternative light and darkness to understand ecological survival of pathogen which will be helpful in the management strategy and for further laboratory evaluation studies.

\section{MATERIALS AND METHODS}

Isolation, purification and identification of pathogen: Plants of guar (Cyamopsis tetragonoloba L.) showing symptoms of root rot were collected from guar fields of PAU, Ludhiana. The samples for isolation were made free from dirt, cut into small bits and surface sterilized with mercuric chloride $\left(\mathrm{HgCl}_{2}\right)$ (Singh et al., 2016). The culture isolated on PDA was purified by single spore isolation (Choi et al., 1999) and identified on the basis of cultural, morphological and molecular characteristics. The isolated pathogen was used for further laboratory studies.

Effect of different cultural media on growth and sporulation of pathogen: Five nutrient media viz.(I) potato dextrose agar [PDA] (peeled potatoes 200.0g, dextrose $20.0 \mathrm{~g}$, agar $20.0 \mathrm{~g}$, ditilled water $1000 \mathrm{ml}$ and pH $5.6 \pm 0.2$ ); (II) oat meal agar [OMA] (Oat meal $30.0 \mathrm{~g}$, agar $20.0 \mathrm{~g}$, distilled water $1000.0 \mathrm{ml}, \mathrm{pH}$ 6.5 \pm 0.03 );(III) guar leaf extract agar [GLEA] (Guar 
leaves $1000.0 \mathrm{~g}$, agar $20.0 \mathrm{~g}$, distilled water $1000.0 \mathrm{ml}$, pH 7.1 \pm 0.02 ); (IV) Czapek's dox agar[CDA] (Sodium nitrate $\left(\mathrm{NaNo}_{3}\right) 2.0 \mathrm{~g}$, Dipotassium hydrogen phosphate [DHP] $\left(\mathrm{K}_{2} \mathrm{HPO}_{4}\right) 1.0 \mathrm{~g}$, Magnesium sulphate $\left(\mathrm{MgSO}_{4}\right.$. $\left.7 \mathrm{H}_{2} \mathrm{O}\right) 0.50 \mathrm{~g}$, Ferrous sulphate $\left(\mathrm{FeSO}_{4} .7 \mathrm{H}_{2} \mathrm{O}\right) 0.01 \mathrm{~g}$, Sucrose $\left(\mathrm{C}_{12} \mathrm{H}_{22} \mathrm{O}_{11}\right) 30.0 \mathrm{~g}$, agar $20.0 \mathrm{~g}$, distilled water $1000 \mathrm{ml}, \mathrm{pH} 7.3 \pm 0.02)$; (V) Richard's agar medium [RA](Potassium nitrate $\left(\mathrm{KNO}_{3}\right) \quad 10.0 \mathrm{~g}$, Potassium monobasic phosphate $\left(\mathrm{KH}_{2} \mathrm{PO}_{4}\right)$ 5.0g, Magnesium sulphate $\left(\mathrm{MgSO}_{4} .7 \mathrm{H}_{2} \mathrm{O}\right) 2.5 \mathrm{~g}$, Ferric chloride $\left(\mathrm{FeCl}_{3}\right.$ $\left.6 \mathrm{H}_{2} \mathrm{O}\right) 0.02 \mathrm{~g}$, Sucrose $\left(\mathrm{C}_{12} \mathrm{H}_{22} \mathrm{O}_{11}\right) 50.0 \mathrm{~g}$, agar $15.0 \mathrm{~g}$, distilled water $1000 \mathrm{ml}, \mathrm{pH} 6.8 \pm 0.03$ ) were tested for growth of pathogen under laboratory conditions at $25 \pm 1^{\circ} \mathrm{C}$. The contents of PDA, OMA and GLEA were boiled in water and filtered through muslin cloth. For the preparation of CDA and RA, sucrose was steam sterilized in an autoclave separately. The agars along with other constituents of the media were dissolved in water and autoclaved separately. The sterilized sugar solution was added to the media aseptically. The agar was added to the extract after filtering through double layered muslin cloth. Final volume of all nutrient medium was made up to 1.0 liter and sterilized. The sterilized media was poured in Petri plates, inoculated with actively growing bit of the fungus and incubated at $25 \pm 1^{\circ} \mathrm{C}$.

Effect of different substrates on growth and sporulation of pathogen: Five different substrates i.e. grains of sorghum, maize, pearl millet, cowpea and guar were tested for mass culturing of the fungi for further studies. One hundred gram of each substrate was soaked in water overnight in $250 \mathrm{ml}$ Erlenmeyer flasks. The excess water which is left after maximum absorption by different grain substrate was drained off and the flasks containing soaked grains were plugged and autoclaved at 15 psi pressure for 30 minutes for three consecutive days. Four flasks of each substrate were used as replicates. The substrate in flasks was inoculated with actively growing $5 \mathrm{~mm}$ mycelial disc of the pathogen under aseptic conditions and inoculated flasks were incubated at $25 \pm 1^{\circ} \mathrm{C}$ in BOD incubator.

Effect of different temperatures on growth and sporulation of pathogen: The growth of the pathogen was determined at minimum, optimum and maximum range of temperature. For this purpose $20 \mathrm{ml}$ of optimized medium was poured into the Petri plates. The Petri plates were inoculated with $5 \mathrm{~mm}$ mycelial discs of inoculum cut with the help of sterilized cork borer from 8 days old culture of pathogen raised on PDA. The inoculated Petri dishes were incubated for 8 days at different temperatures viz., 20, 25, 30 and $35^{\circ} \mathrm{C}$ maintained in separate BOD incubators.

Effect of different pH levels on growth and sporulation of pathogen: To determine the optimum level of $\mathrm{pH}$ for growth of the associated pathogen, $100 \mathrm{ml}$ of the optimized medium was dispensed in Erlenmeyer flasks of $250 \mathrm{ml}$ capacity, and the different $\mathrm{pH}$ levels of 5, 6,
7 and 8 were adjusted by adding $0.1 \mathrm{NHCl}$ or $\mathrm{NaOH}$ solutions and measured by digital $\mathrm{pH}$ meter (ELTOP 3030). The flasks were autoclaved and sterilized Petri plates with nutrient medium were inoculated with 5 mm mycelial discs of inoculum cuts with the help of sterilized cork borer from 8 days old culture raised on the medium. The inoculated Petri dishes were maintained under similar laboratory conditions.

Effect of light and darkness on growth and sporulation of pathogen: To determine effect of light, darkness and alternate light and darkness cycle of 12 hours each on growth of the pathogen associated with wilt, $100 \mathrm{ml}$ of the best medium was dispensed in Erlenmeyer flasks of $250 \mathrm{ml}$ capacity. The flasks were plugged and sterilized in an autoclave at 15 psi pressure for 15 minutes. After autoclaving, the lukewarm media was poured in Petri plates under aseptic conditions and the Petri plates were inoculated with $5 \mathrm{~mm}$ mycelial discs of inoculum cut with the help of sterilized cork borer from 8 days old culture of the pathogen raised on the medium. The inoculated Petri dishes were incubated at $25 \pm 1^{\circ} \mathrm{C}$ maintained in BOD incubator.

Observations recorded and statistical analysis: The observations on radial growth $(\mathrm{mm})$, sporulation (number of spores $\mathrm{ml}^{-1}$ ) and colony colour of the pathogen were recorded continuously after every 24 hours of incubation for 8 days. The colour and quantity of actively growing mycelium was categorized on the basis of visual observations (Kornerup and Wancher, 1978). Each treatment was replicated four times. The sporulation was measured with haemocytometer after 8 days of incubation. Spore suspension was obtained by eluting 5 mycelial discs of $5 \mathrm{~mm}$ size in $5 \mathrm{ml}$ of sterilized distilled water in test tubes. Three tubes were used for each treatment. The tubes were thoroughly shaken for two to three minutes and the eluted spores were counted with the help of haemocytometer. The number of spores per ml was calculated with a haemocytometer, using the formula given by Pathak (1984).

No. of spores per $\mathrm{ml}=\frac{\mathrm{N} \times 1000}{\mathrm{X}}$

where:

$\mathrm{N}=$ Total No. of spores counted/No. of squares,

$\mathrm{X}=$ Volume of mounting solution between the cover glass and above the squares counted.

For each of the above experiments LSD was calculated at 5 per cent level of significance.

\section{RESULTS AND DISCUSSION}

Identification of the pathogen: On the basis of cultural, morphological and molecular characterization, the pathogen was identified as Fusarium solani strain EGY 1 (Singh et al., 2016).

Effect of different media on growth and sporulation of the pathogen: The results revealed that EGY 1 strain of Fusarium solani showed good growth on all 
Simranjit Singh et al. / J. Appl. \& Nat. Sci. 9 (4): 2249 - 2254 (2017)

Table 1. Effect of different culture media on mycelial growth, colour and sporulation of Fusarium solani EGY 1.

\begin{tabular}{|c|c|c|c|c|c|c|c|c|c|c|c|c|}
\hline \multirow{2}{*}{ Culture media } & \multicolumn{9}{|c|}{ Radial growth of mycelium in $\mathrm{mm}$ (days) } & \multirow{2}{*}{$\begin{array}{l}\text { Colony } \\
\text { Colour }\end{array}$} & \multicolumn{2}{|c|}{$\begin{array}{c}\text { Sporulation } \\
\left({\left.\text { conidia } \mathbf{~ m l}^{-1}\right)}^{\text {con }}\right.\end{array}$} \\
\hline & $1^{\text {st }}$ & $2^{\text {nd }}$ & $3^{\text {rd }}$ & $4^{\text {th }}$ & $5^{\text {th }}$ & $6^{\text {th }}$ & $7^{\text {th }}$ & $8^{\text {th }}$ & Mean & & Micro & Macro \\
\hline $\begin{array}{l}\text { Potato dextrose } \\
\text { agar }\end{array}$ & 8.30 & 21.00 & 30.12 & 43.87 & 53.75 & 60.62 & 69.75 & 73.52 & 45.12 & $\begin{array}{c}\text { Creamy } \\
\text { white }\end{array}$ & $1.5 \times 10^{4}$ & $3.1 \times 10^{4}$ \\
\hline Richard's agar & 7.40 & 13.50 & 27.12 & 37.37 & 50.31 & 61.31 & 72.00 & 75.80 & 43.10 & Pale yellow & $1.1 \times 10^{4}$ & $2.5 \times 10^{4}$ \\
\hline $\begin{array}{l}\text { Czapek's dox } \\
\text { agar }\end{array}$ & 7.80 & 20.40 & 32.50 & 48.12 & 62.00 & 71.25 & 80.87 & 84.65 & 50.94 & $\begin{array}{l}\text { Cottony } \\
\text { white }\end{array}$ & $1.8 \times 10^{4}$ & $3.0 \times 10^{4}$ \\
\hline $\begin{array}{l}\text { Guar leaf ex- } \\
\text { tract }\end{array}$ & 8.20 & 18.70 & 30.62 & 42.18 & 56.62 & 65.12 & 66.93 & 70.70 & 44.89 & $\begin{array}{l}\text { Creamy } \\
\text { white }\end{array}$ & $6.0 \times 10^{3}$ & $1.9 \times 10^{4}$ \\
\hline Oat meal agar & 8.00 & 18.50 & 31.18 & 42.43 & 56.62 & 65.62 & 73.12 & 79.00 & 46.56 & $\begin{array}{l}\text { Creamy } \\
\text { white }\end{array}$ & $1.6 \times 10^{4}$ & $2.7 \times 10^{4}$ \\
\hline Mean & 7.93 & 18.41 & 30.36 & 42.80 & 55.86 & 64.78 & 72.53 & 76.26 & & & & \\
\hline
\end{tabular}

$\operatorname{LSD}(\mathrm{p}=0.05)$, Culture medias $=0.26$, Intervals (Days) $=0.33$, Culture medias $\mathrm{x}$ Intervals $($ Days $)=0.73$

Table 2. Effect of different substrates on mycelia growth, colour and sporulation of Fusariumsolani EGY 1.

\begin{tabular}{lcccc}
\hline $\begin{array}{l}\text { Substrates } \\
\text { (grains) }\end{array}$ & $\begin{array}{c}\text { Mycelial } \\
\text { growth }\end{array}$ & Mycelial colour & \multicolumn{2}{c}{ Sporulation after 15 days of incubation $\left(\right.$ conidia $\mathbf{~ m l}^{-\mathbf{1}}$ ) } \\
\cline { 4 - 5 } Maize & Moderate & Creamy white & Micro & Macro \\
Pearl millet & Abundant & Creamy white & $1.7 \times 10^{5}$ & $2.9 \times 10^{5}$ \\
Cowpea & Abundant & Cottony white & $1.9 \times 10^{5}$ & $3.2 \times 10^{5}$ \\
Guar & Scanty & Light brown & $2.0 \times 10^{5}$ & $3.0 \times 10^{5}$ \\
Sorghum & Abundant & Cottony white & $8.2 \times 10^{4}$ & $1.9 \times 10^{4}$ \\
\hline
\end{tabular}

Table 3. Effect of different temperatures on mycelial growth, colony colour and sporulation of Fusarium solani EGY 1.

\begin{tabular}{|c|c|c|c|c|c|c|c|c|c|c|c|c|}
\hline \multirow[t]{2}{*}{$\begin{array}{l}\text { Tempera- } \\
\text { tures }\left({ }^{\circ} \mathrm{C}\right)\end{array}$} & \multicolumn{9}{|c|}{ Radial growth of mycelium in mm (days) } & \multirow[t]{2}{*}{$\begin{array}{l}\text { Colony } \\
\text { Colour }\end{array}$} & \multicolumn{2}{|c|}{$\begin{array}{c}\text { Sporulation } \\
\left(\text { conidia } \mathrm{ll}^{-1}\right)\end{array}$} \\
\hline & $\mathbf{1}^{\text {st }}$ & $2^{\text {nd }}$ & $3^{\text {rd }}$ & $4^{\text {th }}$ & $5^{\text {th }}$ & $6^{\text {th }}$ & $7^{\text {th }}$ & $8^{\text {th }}$ & Mean & & Micro & Macro \\
\hline 20 & 5.00 & 8.09 & 15.77 & 26.34 & 35.26 & 42.96 & 48.72 & 53.42 & 29.44 & Cottony white & $1.5 \times 10^{3}$ & $3.6 \times 10^{3}$ \\
\hline 25 & 7.90 & 20.62 & 32.93 & 48.31 & 62.06 & 71.62 & 81.00 & 84.36 & 51.10 & Cottony white & $1.8 \times 10^{4}$ & $3.1 \times 10^{4}$ \\
\hline 30 & 7.75 & 20.12 & 32.00 & 47.12 & 61.43 & 70.62 & 80.00 & 82.81 & 50.23 & Cottony white & $2.0 \times 10^{4}$ & $3.2 \times 10^{4}$ \\
\hline 35 & 6.98 & 17.06 & 27.68 & 41.31 & 56.58 & 65.46 & 73.84 & 76.59 & 45.69 & Creamy white & $8.2 \times 10^{3}$ & $2.2 \times 10^{4}$ \\
\hline Mean & 6.91 & 16.48 & 27.10 & 40.77 & 53.84 & 62.67 & 70.89 & 74.30 & & & & \\
\hline
\end{tabular}

$\mathrm{CD}(\mathrm{p}=0.05)$, Temperatures $=0.17, \quad$ Intervals (Days) $=0.25$, Temperatures $\mathrm{x}$ Intervals (Days) $=0.51$

Table 4. Effect of different pH levels on mycelial growth, colour and sporulation of Fusarium solani EGY 1.

\begin{tabular}{|c|c|c|c|c|c|c|c|c|c|c|c|c|}
\hline \multirow{2}{*}{ pH levels } & \multicolumn{9}{|c|}{ Radial growth of mycelium in mm (days) } & \multirow{2}{*}{ Colony colour } & \multicolumn{2}{|c|}{$\begin{array}{c}\text { Sporulation } \\
\left(\text { conidia } \mathrm{ml}^{-1}\right)\end{array}$} \\
\hline & $\mathbf{1}^{\mathrm{st}}$ & $2^{\text {nd }}$ & $3^{\text {rd }}$ & $4^{\text {th }}$ & $5^{\text {th }}$ & $6^{\text {th }}$ & $7^{\text {th }}$ & $8^{\text {th }}$ & Mean & & Micro & Macro \\
\hline 5.0 & 7.09 & 19.62 & 31.68 & 46.12 & 60.62 & 69.56 & 79.18 & 82.37 & 49.27 & Creamy white & $1.3 \times 10^{4}$ & $2.7 \times 10^{2}$ \\
\hline 6.0 & 7.90 & 20.62 & 32.93 & 48.31 & 62.06 & 71.62 & 81.00 & 84.43 & 51.11 & Cottony white & $1.7 \times 10^{4}$ & $3.0 \times 10^{4}$ \\
\hline 7.0 & 7.09 & 19.31 & 31.31 & 46.12 & 60.43 & 69.06 & 78.75 & 82.06 & 50.80 & Creamy white & $1.6 \times 10^{4}$ & $2.9 \times 10$ \\
\hline 8.0 & 7.90 & 20.37 & 32.62 & 47.87 & 61.75 & 71.37 & 80.56 & 83.93 & 49.54 & Cottony white & $1.8 \times 10^{4}$ & $3.1 \times 10$ \\
\hline Mean & 7.50 & 19.98 & 32.14 & 47.11 & 61.22 & 70.41 & 79.88 & 83.20 & & & & \\
\hline
\end{tabular}

$\mathrm{CD}(\mathrm{p}=0.05), \mathrm{pH}$ levels $=0.18$, Intervals $($ Days $)=0.25, \mathrm{pH}$ levels $\mathrm{x}$ Intervals $($ Days $)=0.51$

Table 5. Effect of light and darkness on mycelial growth, colony colour and sporulation of Fusarium solani EGY 1.

\begin{tabular}{|c|c|c|c|c|c|c|c|c|c|c|c|c|}
\hline \multirow{3}{*}{ Conditions } & \multirow{2}{*}{\multicolumn{9}{|c|}{ Radial growth of mycelium in mm (days) }} & \multirow{2}{*}{\multicolumn{2}{|c|}{$\begin{array}{l}\text { Colony } \\
\text { Colour }\end{array}$}} & \multirow{3}{*}{$\begin{array}{c}\text { Sporulation } \\
\left(\text { conidia } \mathrm{ml}^{-1}\right)\end{array}$} \\
\hline & & & & & & & & & & & & \\
\hline & $1^{\text {st }}$ & $2^{\text {nd }}$ & $3^{\mathrm{rd}}$ & $4^{\text {th }}$ & $5^{\text {th }}$ & $6^{\text {th }}$ & $7^{\text {th }}$ & $8^{\text {th }}$ & Mean & Micro & Macro & \\
\hline Darkness & 7.75 & 20.37 & 32.75 & 48.12 & 62.00 & 71.25 & 80.87 & 84.31 & 50.93 & Creamy white & $1.8 \times 10^{4}$ & $3.1 \times 10^{4}$ \\
\hline Light & 7.75 & 21.50 & 33.56 & 49.50 & 62.62 & 72.31 & 81.81 & 84.62 & 51.71 & Creamy white & $1.7 \times 10^{4}$ & $2.9 \times 10^{4}$ \\
\hline $\begin{array}{l}\text { Alternating } \\
\text { (12 hrs each) }\end{array}$ & 7.09 & 19.62 & 31.21 & 45.12 & 60.52 & 69.56 & 79.77 & 82.36 & 49.53 & Creamy white & $1.5 \times 10^{4}$ & $2.7 \times 10^{4}$ \\
\hline Mean & 7.53 & 20.50 & 32.66 & 47.91 & 61.75 & 71.04 & 80.62 & 83.77 & & & & \\
\hline
\end{tabular}

$\mathrm{CD}(\mathrm{p}=0.05)$, Conditions $=0.21$, Intervals $($ Days $)=0.33$, Conditions $\mathrm{x}$ Intervals $($ Days $)=0.58$

the tested media (Plate 1). The mean radial growth varied from $43.10 \pm 24.30$ to $50.94 \pm 26.71 \mathrm{~mm}$ on all the tested media (Table 1). The maximum vegetative growth of $84.65 \mathrm{~mm}$ was supported by Czapek's dox agar after $8^{\text {th }}$ day of inoculation. This was followed by oat meal agar with radial growth of $79.00 \mathrm{~mm}$ and Richards agar with radial growth of $75.80 \mathrm{~mm}$. Least vegetative growth was observed on PDA and guar leaf extract with radial diameter of 73.52 and $70.70 \mathrm{~mm}$ respectively. All the tested media differed statistically and significantly among themselves, when tested on 5 per cent significant level. Based on visual observations, the colour of the fungal mycelium varied from cottony white on Czapek's dox agar, pale yellow on 


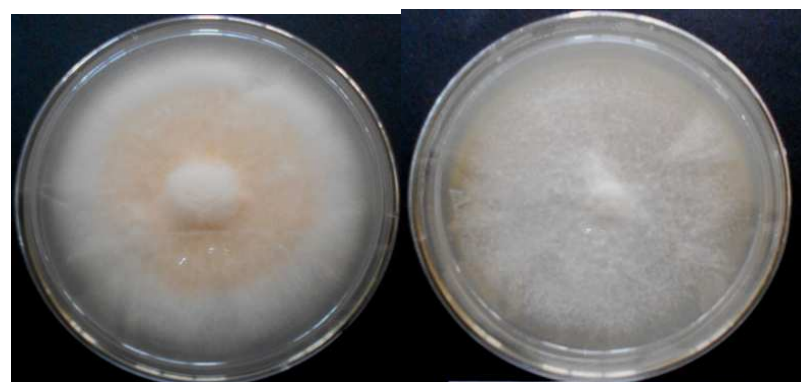

Richard's agar

Oat meal agar

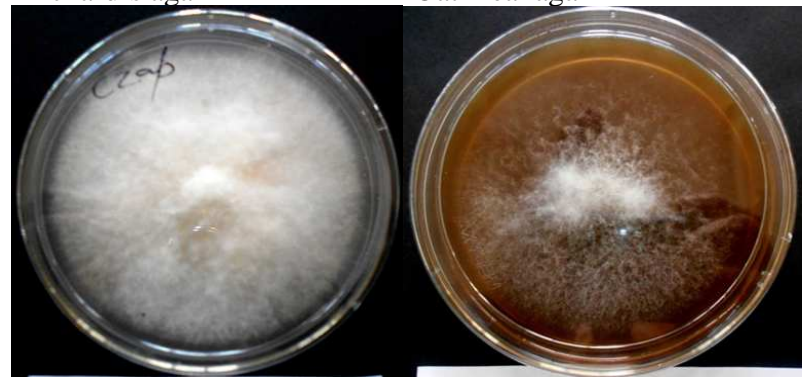

Czapek dox agar

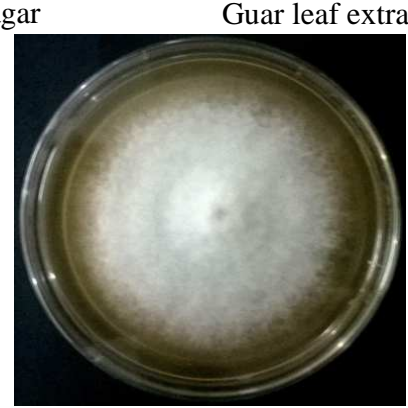

Potato dextrose agar

Plate 1. Growth pattern of Fusarium solani EGY 1 on given five semi-solid media.

Richard's agar and creamy white on potato dextrose agar, guar leaf extract and oat meal agar respectively. Sporulation varied from $1.9 \times 10^{4}$ to $3.1 \times 10^{4}$ macroconidia $\mathrm{ml}^{-1}$ and $6.0 \times 10^{3}$ to $1.8 \times 10^{4}$ microconidia $\mathrm{ml}^{-}$ ${ }^{1}$ on different tested media. All the media supported the production of both microconidia and macroconidia. Maximum sporulation was achieved on Czapek's dox agar medium with $1.8 \times 10^{4}$ microconidia $\mathrm{ml}^{-1}$ and 3.0 x $10^{4}$ macroconidia $\mathrm{ml}^{-1}$ respectively and minimum sporulation was observed on guar leaf extract medium with $6.0 \times 10^{3}$ microconidia $\mathrm{ml}^{-1}$ and $1.9 \times 10^{4}$ macroconidia $\mathrm{ml}^{-1}$ respectively.

The nutrient contents in Czapek's Dox agar, oat meal agar and Richard's agar might be favourable for the growth and development of Fusarium solani EGY 1. Chittem and Kulkarni (2008) also observed that maximum radial growth of $F$. oxysporum f. sp. gerberae was on oat meal agar $(90.00 \mathrm{~mm})$ followed by Richard's agar (86.00 mm), Czapek's Dox agar (84.67 mm) and potato dextrose agar $(83.67 \mathrm{~mm})$. Sporulation was also abundant on Czapek's Dox agar and gerbera leaf extract media. Czapek's Dox agar and potato dextrose agar were also found the best medium by Khilare and
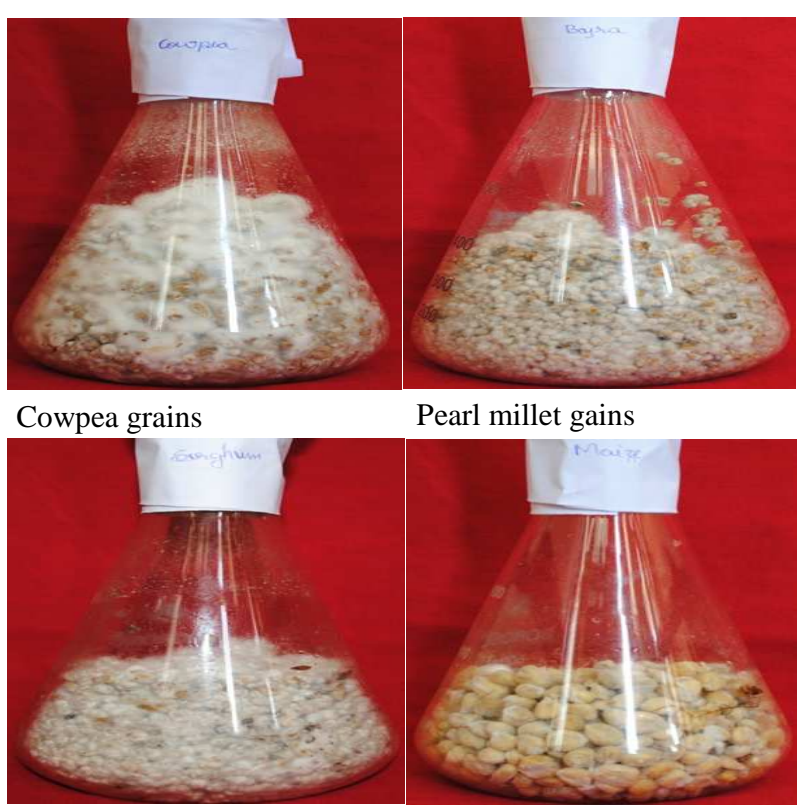

Sorghum grains

Maize grains

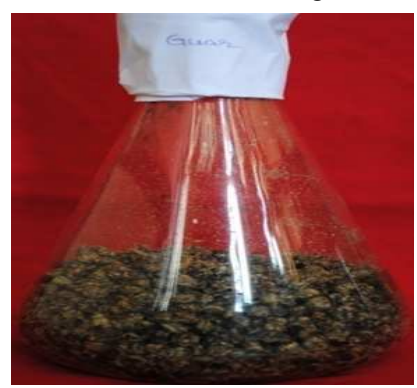

Guar grains

Plate 2. Effect of different substrates on mycelial colour and growth of Fusarium solani EGY1.

Ahmed (2012) for growth of F. oxysporum f. sp. ciceri. Effect of different substrates on growth and sporulation of pathogen: The substrates viz., soaked grains of sorghum, pearl millet, maize, cowpea and guar were used to find out the best substrate for mass culturing of the fungus. The visual observations recorded after 15 days of incubation showed that colour of mycelium was fluffy white on sorghum and cowpea grains, suppressed creamy white on pearl millet and maize grains and light brown on guar grains (Plate 2). Abundant mycelial growth was found on sorghum, cowpea and pearl millet grains, whereas growth was moderate on maize grains and scanty on guar grains. The sporulation varied from $8.2 \times 10^{4}$ to $2.1 \times 10^{5}$ spores $\mathrm{ml}^{-1}$ and $1.9 \times 10^{4}$ to $3.4 \times 10^{5}$ spores $\mathrm{ml}^{-1}$ respectively in terms of both microconidia and macroconidia production. The maximum production of microconidia and macroconidia was found on sorghum grains with $2.1 \times 10^{5}$ and $3.4 \times 10^{5}$ spores $\mathrm{ml}^{-1}$ respectively. Sporulation on sorghum grains was followed by pearl millet grains $\left(1.9 \times 10^{5}\right.$ microconidia $\mathrm{ml}^{-1}$ and $3.2 \times 10^{5}$ macroconidia $\left.\mathrm{ml}^{-1}\right)$, cowpea grains $\left(2.0 \times 10^{5}\right.$ microconidia $\mathrm{ml}^{-1}$ and $3.0 \times 10^{5}$ macroconidia $\left.\mathrm{ml}^{-1}\right)$ and maize grains (1.7 
x $10^{5}$ microconidia $\mathrm{ml}^{-1}$ and $2.9 \times 10^{5}$ macroconidia $\mathrm{ml}^{-}$ $\left.{ }^{1}\right)$. Least sporulation was observed on guar grains with microconidia production of $8.2 \times 10^{4}$ sporesml $^{-1}$ and macroconidia production of $1.9 \times 10^{4}$ spores $\mathrm{ml}^{-1}$ respectively showed in Table 2 .

Both the mycelial growth as well as sporulation was maximum on sorghum grains. The nutritional composition as well as size of the grains might be suitable for for growth and sporulation of the fungus. Similarly Diarra et al (1996) also observed that highest production of macroconidia occurred on sorghum glumes, whereas the highest microconidia production occurred on sorghum fibre. Sorghum grains were also used as nutritional substrate by Luckew et al. (2012) for mass culturing of Fusarium virguliforme causing sudden death syndrome in soybean.

Effect of different temperatures on growth and sporulation of the pathogen: It is evident from Table 3 that the mean radial growth of the fungus was found to be significantly different at all the tested temperatures i.e. 20, 25, 30 and $35^{\circ}$ Con Czapek's dox agar medium as temperature has marked effect on growth of the fungus. The mean mycelial radial growth varied from $29.44 \pm 17.36 \mathrm{~mm}$ at $20^{\circ} \mathrm{C}$ to $51.10 \pm 26.63 \mathrm{~mm}$ at $25^{\circ} \mathrm{C}$. The maximum radial growth of $84.36 \mathrm{~mm}$ was observed at $25^{\circ} \mathrm{C}$ followed by $82.81 \mathrm{~mm}$ at $30^{\circ} \mathrm{C}$ on $8^{\text {th }}$ day of incubation as it is the optimum temperature range for growth of most of the mesophilic fungi. Least radial growth $(53.42 \mathrm{~mm})$ was recorded at $20^{\circ} \mathrm{C}$ whereas radial growth of $76.59 \mathrm{~mm}$ was found at $35^{\circ}$ C.At low temperatures the growth is retarded due to low metabolic rate of the fungus whereas at high temperatures the metabolism increases which results in exhaustion of nutrients. The colour of mycelium was cottony white at $20^{\circ} \mathrm{C}$ and $30^{\circ} \mathrm{C}$, whereas it was creamy white at $35^{\circ} \mathrm{C}$.

It is evident from the data that the pathogen produced various extents of sporulation on Czapek dox agar at different temperatures of incubation. The highest sporulation was recorded at $30^{\circ} \mathrm{C}\left(2.0 \times 10^{4}\right.$ microconidia $\mathrm{ml}^{-1}$ and $3.2 \times 10^{4}$ macroconidia $\mathrm{ml}^{-1}$ ) followed by $25^{\circ} \mathrm{C}\left(1.8 \times 10^{4}\right.$ microconidia $\mathrm{ml}^{-1}$ and $3.1 \times 10^{4}$ macroconidia $\left.\mathrm{ml}^{-1}\right)$ and $35^{\circ} \mathrm{C}\left(8.2 \times 10^{3}\right.$ microconidia $\mathrm{ml}^{-1}$ and $2.2 \times 10^{4}$ macroconidia $\left.\mathrm{ml}^{-1}\right)$. Minimum sporulation $\left(1.5 \times 10^{3}\right.$ microconidia $\mathrm{ml}^{-1}$ and $3.6 \times 10^{3}$ macroconidia $\mathrm{ml}^{-1}$ ) was observed at $20^{\circ} \mathrm{C}$.

According to present studies maximum mycelial growth and sporulation was achieved at $25^{\circ} \mathrm{C}$ and $30^{\circ}$ $\mathrm{C}$ respectively. Chaturvedi et al. (2003) also found that optimum temperature for growth and sporulation of $F$. oxysporum and $F$. solani was $25^{\circ} \mathrm{C}$. Gangadhara et al. (2010) also observed that maximum growth of Fusarium oxysporum f.sp. vanilla after seven days of incubation was at $25^{\circ} \mathrm{C}$ which was drastically reduced below $15^{\circ} \mathrm{C}$ and no growth observed at $40^{\circ} \mathrm{C}$, because low temperature inhibits the normal metabolic processes of the fungus. Similarly Khilare and Ahmed
(2012) observed that the growth and sporulation of Fusarium oxysporum f. sp. ciceri was maximum at $30^{\circ}$ $\mathrm{C}\left(24.7\right.$ conidia $\left.\mu \mathrm{l}^{-1}\right)$ after seven days of inoculation, which was reduced drastically below $15^{\circ} \mathrm{C}$ and above $35^{\circ} \mathrm{C}$. Adeniyi et al (2011) also reported that the optimum temperature for growth of Fusarium was $25^{\circ} \mathrm{C}$. Similarly Merlin et al (2013) and Kausar et al (2009) also found that temperature of $25 \pm 2{ }^{\circ} \mathrm{C}$ supported the maximum growth of $F$. solani.

Effect of different $\mathrm{pH}$ levels on growth and sporulation of the pathogen: The investigations showed that in Table 4, there were significant differences among pH levels viz., 5.0, 6.0, 7.0 and 8.0 respectively and the mean radial growth of the pathogenraisedon Czapek's dox agar. The mean radial growth of Fusarium solani EGY 1 varied from $49.27 \pm 26.23$ to 51.11 $\pm 26.64 \mathrm{~mm}$. Increasing trend in radial growth was noticed from $\mathrm{pH} 5.0$ to 6.0 and thereafter growth showed a decreasing trend from $\mathrm{pH} 7.0$ to 8.0. Maximum radial growth of $84.43 \mathrm{~mm}$ with mean $51.11 \pm$ 26.64 was recorded at $\mathrm{pH} 6.0$ after $8^{\text {th }}$ day of incubation. Minimum mean radial growth of $49.27 \pm 26.23$ $\mathrm{mm}$ was found at $\mathrm{pH} 5.0$. At $\mathrm{pH} 7.0$ to 8.0 , mean radial growth of $50.80 \pm 26.53$ and $49.54 \pm 26.14 \mathrm{~mm}$ was observed respectively. Colony colour also varied from cottony white to creamy white. Maximum sporulation was recorded at $\mathrm{pH} 8.0$ in terms of production of $1.8 \mathrm{x}$ $10^{4}$ microconidia $\mathrm{ml}^{-1}$ and $3.1 \times 10^{4}$ macroconidia $\mathrm{ml}^{-1}$ followed by $\mathrm{pH} 6.0\left(1.7 \times 10^{4}\right.$ microconidia $\mathrm{ml}^{-1}$ and $3.0 \mathrm{x}$ $10^{4}$ macroconidia $\left.\mathrm{ml}^{-1}\right)$ and $\mathrm{pH} 7.0\left(1.6 \times 10^{4}\right.$ microconidia $\mathrm{ml}^{-1}$ and $2.9 \times 10^{4}$ macroconidia $\left.\mathrm{ml}^{-1}\right)$ respectively. Least sporulation $\left(1.3 \times 10^{4}\right.$ microconidia $\left.\mathrm{ml}^{-1}\right)$

El-Sayed et al (2008) observed that best growth of $F$. oxysporum f. sp. Lycopersici and F. solaniwas promoted at $\mathrm{pH}$ 8.0. Most suitable $\mathrm{pH}$ level according to Gangadhara et al (2010) for growth of $F$. oxysporum f.sp. vanillae isolates was also 5.0 to 6.0. Gupta et al (2010) also found that maximum mycelial mass production of F.oxysporumf.sp. psidii and F. solani isolates was 5.5 followed by 5.0 while maximum sporulation was obtained at $\mathrm{pH} 6.0$ to 6.5 which indicated that Fusarium spp. favours acidic $\mathrm{pH}$ for its growth and sporulation.

Effect of light and darkness on growth and sporulation of the pathogen: Data presented in Table 5 revealed that statistical differences in mean radial growth of fungus Fusarium solani EGYwere observed when grown under light, darkness and alternating conditions (Plate 9)on Czapek's dox agar. Maximum mean creamy white growth of $51.71 \pm 26.72 \mathrm{~mm}$ was achieved under light conditions, whereas $50.93 \pm$ $26.65 \mathrm{~mm}$ radial growth of fungus was observed when kept under dark condition. Alternating conditions of 12-12 hours light-dark cycle showed radial growth of $49.53 \pm 22.41 \mathrm{~mm}$. Data on sporulation also indicated that maximum sporulation in terms of microconidia $\left(1.8 \times 10^{4}\right.$ spores $\left.\mathrm{ml}^{-1}\right)$ and macroconidia $\left(3.1 \times 10^{4}\right.$ 
spores $\mathrm{ml}^{-1}$ ) production was achieved under dark conditions. Light conditions recorded sporulation of $1.7 \mathrm{x}$ $10^{4}$ microconidia $\mathrm{ml}^{-1}$ and $2.9 \times 10^{4}$ macroconidia $\mathrm{ml}^{-1}$ followed by alternating conditions with $1.5 \times 10^{4} \mathrm{mi}^{-}$ croconidia $\mathrm{ml}^{-1}$ and $2.7 \times 10^{4}$ macroconidia $\mathrm{ml}^{-1}$ respectively.

The results revealed that maximum fungal growth and sporulation were observed under continuous light conditions. This might be due to more responsiveness of fungus under light conditions. Kausar et al (2009) found that continuous light was more suitable for maximum growth of Fusarium solani with colony diameter of $16.67 \mathrm{~mm}$ when exposed for seven days. The colony diameter at continuous darkness was decreased to $11.5 \mathrm{~mm}$, whereas it was $8.9 \mathrm{~mm}$ when exposed to alternate $12 \mathrm{hrs}$ of light and $12 \mathrm{hrs}$ of darkness. El-Sayed et al (2008) also observed that continuous light induced the maximum growth in case of $F$. oxysporum f.sp. Lycopersici and $F$. solani. Continuous light and white light were also found ideal by Bhale (2012) for maximum radial growth and spore germination of $F$. oxysporum $\mathrm{f}$. sp. spinaciae. The dark conditions were found to be favourable by Velmurugan et al. (2009) as incubation in total darkness increased the biomass, extracellular and intracellular pigment production in all the tested fungi including $F$. verticilloides. Adeniyi et al (2011) found that alternating 12 hours light plus 12 hours darkness with colony diameter of $61.0 \mathrm{~mm}$ was more suitable for growth of Fusarium than continuous darkness with colony diameter of $33.5 \mathrm{~mm}$.

\section{Conclusion}

Czapek's dox media was found to be best for growth and sporulation of fungus $F$. solani EGY 1. For mass multiplication of the fungus, sorghum grains were proved to be the best substrate. Slightly acidic $\mathrm{pH}$ of 6.0 at $25^{\circ} \mathrm{C}$ favoured the radial growth of the fungus under continuous light conditions, whereas sporulation was highest at slightly alkaline $\mathrm{pH}$ of 8.0 at $30^{\circ} \mathrm{C}$ in dark .

\section{REFERENCES}

Adeniyi, D.O., Orisajo, S.B., Fademi, O.A., Adenuga, O.O. and Dongo, L.N. (2011). Physiological studies of fungi complexes associated with cashew diseases. Journal of Agricultural and Biology Science, 6:34-38

Anonymous (2014). An analysis of performance of guar crop in India. Pp. 8-11. CCSNIAM Jaipur. www.ccsniam.gov.in

Ayub, M., Khalid, M., Tariq, M., Nadeem, M.A. and Naeem, M. (2011) Effect of different seedling densities and nitrogen levels on growth, forage yield and quality attributes of cluster (Cyamopsis tetragonoloba Tuab). Journal of Agricuture Technology, 7(5):1409-1417

Bhale, U. N. (2012). Physiological studies of fungicide resistant and sensitive Fusarium oxysporum f.sp. spinaciae. International Journal of Ayurvadic and Herbal Medicine 2:171-75

Chaturvedi, V. C., Gupta, S., Gupta, R. and Shukla, D. N. (2003).Effect of temperature on growth and sporulation of some Fusarium species. Bioved, 14:33-35

Chittem, K. and Kulkarni, S. (2008). Effect of media on the growth of Fusarium oxysporum f.sp. gerberae and Fusarium oxysporum f.sp. dianthi. Karnataka Journal Agricultural Sciences, 21:303-304

Choi, Y.W., Hyde, K.D. and Ho, W.H. (1999). Single spore isolation of fungi. Fungal Diversity, 3:29-38

Diarra, C., Ciotola, M., Hallett, S.G., Hess, D.E. and Watson, A.K. (1996). Mass production of Fusarium oxysporum (M12-4A), a biocontrol agent for Strigahermonthica. Proc $9^{\text {th }}$ IntSymp "Biological Control of weeds". pp 14952. Nebraska, America

El-Sayed, A. F., Yasser, M. S., and Nasser (2008) Effect of enviornmental conditions on wilting and root rot fungi pathogenic to solanaceous plants. Plant Pathology Journal 7:27-33

Gangadhara, N. B., Nagaraja, R., Basavaraja, M. K. and Krishna, N. R. (2010). Variability studies of Fusarium oxysporum f.sp. Vanilla isolates. International Journal of Science and Nature, 1:12-16

Gupta, V.K., Misra, A.K. and Gaur, R.K. (2010). Growth characteristics of Fusarium spp. causing wilt disease in Psidium guajava L. in India. Journal of Plant Protection Research, 50:452-462

Kausar, P., Chohan, S. and Parveen, R. (2009). Physiological studies on Lasiodiplodia theobromae and Fusarium solani, the cause of Shesam decline. Mycopathology, 7:35-38

Khilare, V.C. and Ahmed, R. (2012).Effect of different media, $\mathrm{pH}$ and temperature on the growth of Fusarium oxysporum f.sp. ciceri causing chickpea wilt. International Journal of Advances in Biology, 12:99-102

Kornerup, A. and Wancher, J.H. (1978). Handbook of Colour. 3rd ed. Eyre Methuen Ltd; London, Methuen

Luckew, A., Cianzio, S. and Leandro, L. (2012). Screening method for distinguishing soybean resistance to Fusarium virguliforme in resistant $\mathrm{x}$ resistant crosses. Crop Science, 52:1-9

Merlin, J.N., Christhudas, I.V.S.N., Kumar, P.P. and Agastian, P. (2013). Optimization of growth and bioactive metabolite production: Fusarium solani. Asian Journal of Pharmaceutical and Clinical Research. 6: 98-103

Pareek, V. and Varma,R. (2015). Fusarium solani a dominant seed borne pathogen in seeds of cluster bean grown in Rajasthan. Bioscience and Biotechnology Research Communication, 8(1): 29-34

Pathak, V.N. (1984) Laboratory Manual of Plant Pathology. Second edition. Oxford and IBH Publishing Co. Pvt. Ltd., New Delhi: 11-12

Singh, S., Rani, U., Sirar,i A. and Tiwana, U. S. (2016). Identification of the pathogen associated with the wilt of guar (Cyamopsis tetragonoloba). Plant Disease Research, 31(1): 6-9

Sortino, O. and Gresta F. (2007) Growth and yield Grain yield response and chilopartillus infestation performance of five guar cultivars in a Mediterranean diverse sorghum crop intercrop management. South environment. Italian Journal of Agronomy, 4:359-364

Velmurugan, P., Lee, Y.H., Venil, C.K., Lakshmanaperumalsamy, P., Chae, J.C. and Oh, B.T. (2009). Effect of light on growth, intracellular and extracellular pigment production by five pigment-producing filamentous fungi in synthetic medium. Journal of Bioscience and Bioengineering, 20:230-231 